Кよる減収推定について. 雑草研究 2, 86〜90 (1963).

8）鈴木光喜・須藤孝久 : 水田雑草の発生生態 第 1 報 温度と発生と の関係. 雑草研究 20 (3), 105 109 (1975).
9）鈴木光喜・須藤孝久 : 水田雑草の発生生態 第 2 報 発生期間と発 生率. 雑草研究 20 (3), 109 113 (1975).

(1975 年 6 月 3 日受付)

\title{
Emergence of Weeds in Paddy Rice Fields
}

3. Weed Emergence and Weed Damage in Paddy Rice Fields

\author{
Mitsuyoshi SuzukI and Takahisa SuTo
}

Akita Prefectural Agricultural Experiment Station, Akita

\section{Summary}

Changes in weed emergence with time and the relation of weeding to weed damage were examined in the transplanted rice fields, in which young rice seedlings were transplanted at different three dates with transplanter. Results obtained were as follows:

1. Seventeen species of eleven families were found in the experimental fields.

2. Emergence of Echinochloa crus-galli, Aneilema japonica and Eleocharis congesta decreased with the deley of transplanting. On the other hand, amounts of emergence of Cyperus difformis and Elatine triandra were scarcely changed among transplanting times.

3. Twenty-five to fifty-four percent and ca. ninety percent of the final amounts of emergence were emerged within 12 days and 43 days after puddling, respectively. Period of complete emergence, however, varied with transplanting time, and it was 70,60 or 50 days in early, ordinary or late season culture, respectively. Elatine triandra, Monochoria vaginalis and Eriocaulon robustinus, among weed species found in fields, continued to emerge until later growing season.

4. Complete weeding for 40 days after transplanting eliminated the yield loss by weeds in early or ordinary season culture.

5. When weeds were permitted to grow without any control, weeds rapidly increased their weight around 40 to 60 days after transplanting and strongly inhibited the tillering of rice, which was the major cause for yield loss.

\section{熟畑化過程における雑草植生の变遷に関する研究}

\section{第 3 報 火山灰黒ボク地带における雑草群落の平均反応数と土壤酸度との関係*}

$$
\text { 新潟大学農学部附属農場 菅 原 清 康 }
$$

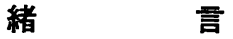

筆者は第 1 報 ${ }^{12)}$ において，火山灰黒ボク土壃地帯の原 野および畑地に発生した 37 草種を土壌酸度の強弱によ
って 6 段階に分類し，第 2 報 $^{13)}$ で土銥酸度の測定に当っ て適正な採土位置や採土方法を究明した。また，上記の 尺度が求められた新潟県中蒲原郡村松町石曾根地区の火 山灰黒ボク土壌に適応できる雑草群落を全体の形として

* 昭和 50 年 4 月 24 日, 雑草防除研究会第 14 回講演会において発表 
表わす簡単な数值が, 熟畑化過程の指標たりらることも 指摘した。しかし, 他の異なる地区や土㙵について実験 した成果が見当らないので, 次段階として, まず新潟県 内の火山灰黒ボク土塎からなる異なる地域を選定し, 同 じ方法で得られた数值が果して土㙵や熟畑化過程の指標 となりうるや否や，その適，不適を究明せんとした。

\section{実験材料ならびに実験方法}

実験を行なった場所は，第 1 表に示寸通り新潟県内の 5 地区である。これら各地区の熟畑，未熟畑ならびにそ
れら戋場のベースになっている近接の原野それぞれ $50 \mathrm{a}$ を選定し，その $50 \mathrm{a}$ を $25 \times 10 \mathrm{~m}$ の $2.5 \mathrm{a}$ に 20 等分し, それらの中心を基点として $2.0 \times 1.65 \mathrm{~m}$ の $3.3 \mathrm{~m}^{2}$ のプ ロットを設定した。雑草の調査は, プロット内に存在し ている全草種名を記録し，整理に当っては $1 \sim 5$ の序 数 ${ }^{12)}$ 有する草種の全序数を集計し，その総計を序数保 有の草種数で除し，その数値をプロット内における雑草 群落の平均反応数とした。一方, 数值を求めたプロット 内から任意に選定した 5 力所の地下 $5 \mathrm{~cm}$ の位置から採 土を行ない，それらをよく混合した試料を，採土直後，

第 1 表 調査地区の概要

\begin{tabular}{|c|c|c|c|c|c|c|c|c|c|}
\hline \multirow{2}{*}{ 調査地区 } & \multirow{2}{*}{$\begin{array}{c}\text { 標 高 } \\
\text { 海 抜 } \\
(\mathrm{m})\end{array}$} & \multirow{2}{*}{$\begin{array}{l}\text { 年 平均 } \\
\text { 気 } \\
\left({ }^{\circ} \mathrm{C}\right)^{\text {温 }}\end{array}$} & \multirow[b]{2}{*}{ 種 } & \multirow{2}{*}{$\begin{array}{c}\text { 開蓝後 } \\
\text { (年) }\end{array}$} & \multicolumn{3}{|c|}{ 土袞の化学的性質 } & \multirow[b]{2}{*}{ 主要な作付作物 } & \multirow[b]{2}{*}{ 摘 要 } \\
\hline & & & & & $\underset{(\mathrm{KCl})}{\mathrm{pH}}$ & $\mathrm{y}_{1}$ & $\begin{array}{l}\text { 石灰 } \\
\text { 飽犁度 } \\
(\%)\end{array}$ & & \\
\hline \multirow{3}{*}{ 新潟県中蒲原郡村松町石賏根 } & \multirow{3}{*}{24} & \multirow{3}{*}{13.1} & 原 & - & 4.05 & 16.25 & 6.39 & - & \multirow{3}{*}{9 月 20 日調査 } \\
\hline & & & 未熟畑 & 4 & 4. 68 & 6.45 & 22.30 & ダイズ & \\
\hline & & & 鰵 & 25 & 5.75 & 0.19 & 65.36 & スイカ踝 & \\
\hline \multirow{3}{*}{ ” 络渡郡金井町釷故 } & \multirow{3}{*}{87} & \multirow{3}{*}{13.8} & 原 & 一 & 3. 72 & 17.52 & 4.05 & - & \multirow{3}{*}{9 月 12 日 》 } \\
\hline & & & 末 熟畑 & 6 & 4.67 & 5.96 & 25.20 & タバョ,ダイズ & \\
\hline & & & 熟 & 57 & 5.86 & 0.22 & 73.86 & アスキ,ネギ, ハクサイ & \\
\hline \multirow{3}{*}{ ”中䫇城郡妙高高原町関川 } & \multirow{3}{*}{672} & \multirow{3}{*}{12.4} & 原 & - & 4.48 & 12.36 & 10.20 & - & \multirow{3}{*}{9 月14 日 } \\
\hline & & & 末就畑 & 5 & 5.20 & 4.82 & 27.64 & ソパ & \\
\hline & & & 熟 & 37 & 6.18 & 0.12 & 86.30 & ダイコン, ノザワナ & \\
\hline \multirow{3}{*}{ " 新発田市字曼䫈 } & \multirow{3}{*}{75} & \multirow{3}{*}{13.0} & 原野 & 一 & 4.34 & 15.67 & 5.16 & - & \multirow{3}{*}{9 月 15 日 } \\
\hline & & & 末熟畑 & 4 & 5.06 & 5. 78 & 25.38 & タパコ & \\
\hline & & & 熟 & 29 & 5.85 & 0.26 & 67.26 & タ゚インン, ネギ,ナス & \\
\hline \multirow{3}{*}{ ”十日町市字中在家 } & \multirow{3}{*}{275} & \multirow{3}{*}{12.8} & 原野 & - & 4.62 & 14.31 & 8. 05 & - & \multirow{3}{*}{9 月 17 日 } \\
\hline & & & 末 㷫 畑 & 5 & 5.47 & 8.78 & 28.48 & ソパ, タバ & \\
\hline & & & 熟 & 約 50 & 6.22 & 0.34 & 80.22 & ナス, キウリ，ハクサイ & \\
\hline
\end{tabular}

注）土堙はそれぞれ $50 \mathrm{a}$ から地下 $5 \mathrm{~cm}$ の位置 30 地点を採土し，分析に供す。

矢木式簡易土壌検定器で土壌酸度を測定し，1検体 5 回 反覆の平均值を求めた。ついで雑草群落の平均反応数と 土壤酸度との関係を検討した。

\section{実験結果ならびにその考察}

本調查を実施した 5 調查地区の原野および畑地に存在し た草種名ならびに草種数は第 2 および第 3 表に示す通り である。

第 2 表によれば， 5 調査地区の原野区に発生した草種 は序数 1 のチガヤ, シバ, ススキ, アブラススキ, コブ ナグサ, 序数 2 のドクダミ, タケニグサ, ゲンノショウ コ，イタドリ，ワラビ，スギナ, カワラケツメイ, 序数 3 に属するエノコログサ, 序数 0 のヨモギ, ナズナ, オ オマツヨイグサなどのほか, 序数不明の $11 \sim 15$ 種で,
その大部分が山野草で占められている。熟烟区では序数 2 のゲンノショウコ, ワラビ, スギナ, カワラケツメイ なども認められるが, その大部分は序数 3 のヒメスイ バ, オオバコ, オランダミミナグサ, サクラタデ, アカ ザ，メヒシバ，エノコログサ，スズメノカタビラ, 序数 4 のイヌガラシ，コゴメカヤツリ，ノミノフスマ，コニ シキソウ, カラスビシャク, 序数 5 のツュクサ, ツメク サ，ハナイバナ，八コベ，ザクロソウ，エノキグサ，ス ベリヒユ, 序数 0 のヨギ, ナズナ, オオマツョイグ サ, ギシギシなどのほか序数不明の $2 \sim 9$ 種が加わり, 烟地雑草に占められている。また, 未熟烟区では, 序数 $0 \sim 5$ の 34 草種のほか山野草や畑地雑草 13 18 種を含 み, 複雑な混合群落の形態を示している。以上のように 原野区では概祇山野草に, 熟畑では畑地雑草に限定さ 
第 2 表 5 調査地区に存在した雑草草種

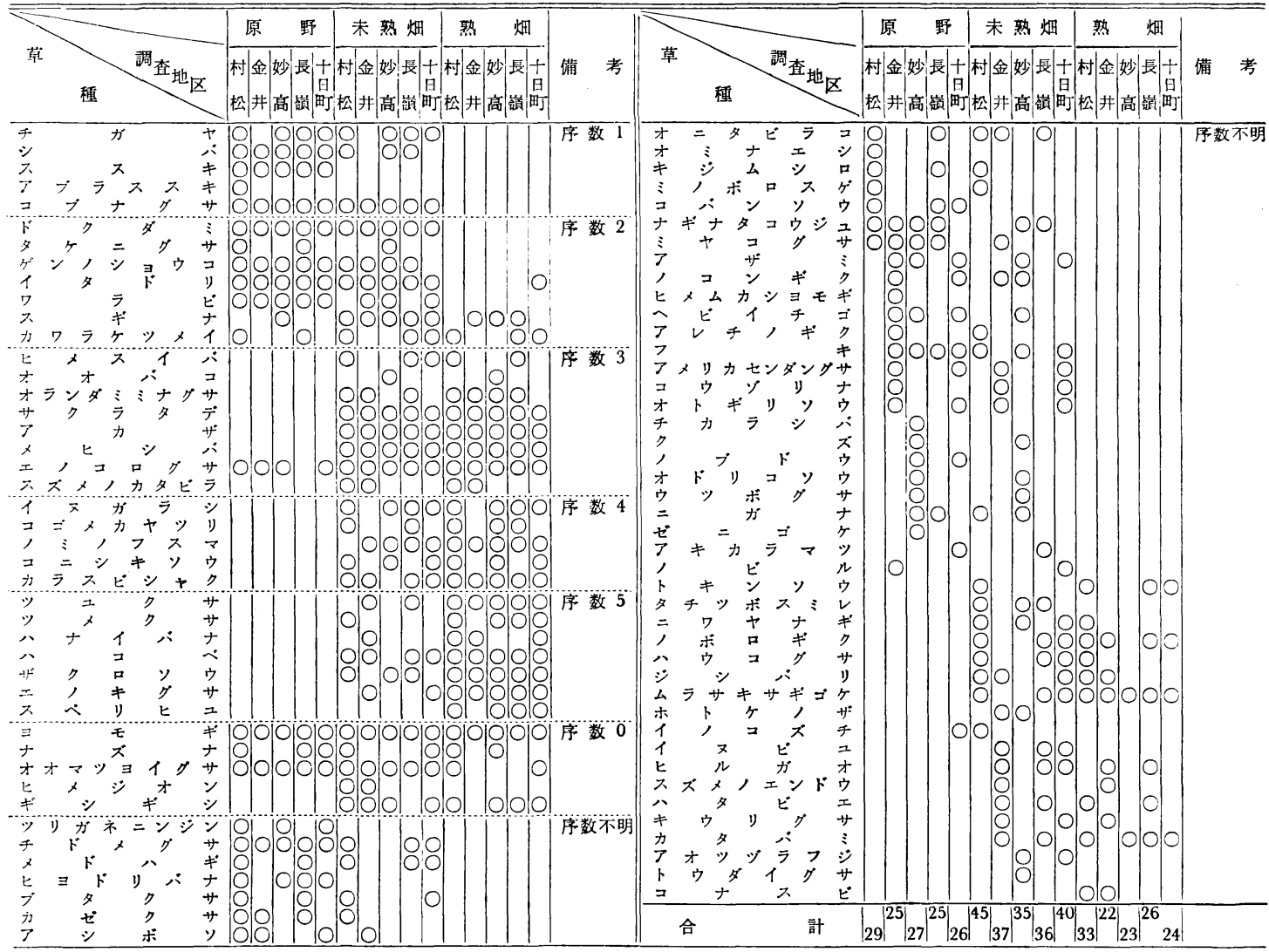

注） 1 地区は $3.3 \mathrm{~m}^{2}$ のプロット各 20

れ, 未熟畑では両者が重複した植生を示していることが 5 調查区の共通点として認められた。

ついで第 3 表によれば，それぞれの調査地区の原野区 および畑地区全体を通じてその存在を確認した全草種数 およびその中で 0 〜 の序数を有する草種数は, 村松地 区で 64 種中 36 種, 金井地区が 51 種中 26 種, 妙高高原 地区が 54 種中 30 種, 長嶺地区が 52 種中 29 種ならびに 十日町地区が 59 種中 27 種である。また, 5 調査地区の
各 20 プロット全体を通じ原野区に存在した草種数およ びそのうち 5 地区に共通している草種数は 25 29 種中 10 種, 未熟畑区が 35 45 種中 10 種ならびに熟畑区で は 22 種中 8 種が示されている。さらに， 5 調查地区の 原野および畑地のそれぞれ $3.3 \mathrm{~m}^{2}$ 当り 1 プロットの平 均草種数, およびその中に含まれている序数 1 以上を有 する草種数は，原野区では 4.8 7.1 種中 3.5 4.5 種, 熟畑区では 5.5 7.9 種中 4.7 6.3 種ならびに未熟畑区

第 3 表 試験地区の草種数

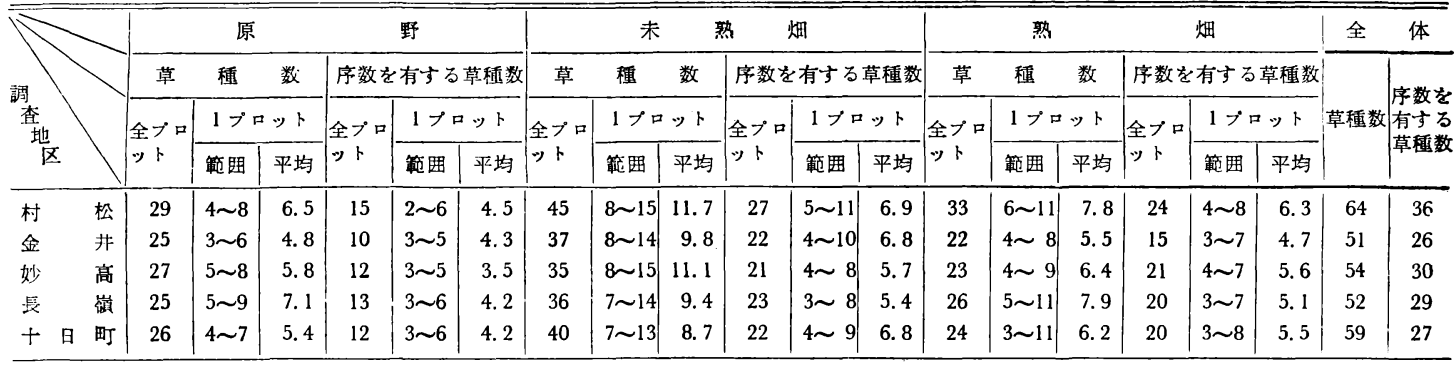

注） 1 プロットは $2 \times 1.65 \mathrm{~m}$ の $3.3 \mathrm{~m}^{2}$, 全プロットは $3.3 \mathrm{~m}^{2}$ のブロット 20 
では 8.7 11. 7 種中 5. 4 6.9 種となっている。このよ らに供試した 5 つの調查地区の原野および畑地に発生し た雑草草種の特徴や草種数が概祙同じ傾向を示し，ま た，それぞれに共通して発生した草種が比較的多かった 点, さらに, それぞれの各プロット内に序数を有する草 種が大差のない状態で存在した点などが明らかになっ た。しかして，このことは第 1 報 ${ }^{12)} て ゙$ 示した内容，すな わち雑草草種の土壤酸度に対する強弱の一覧表といら尺 度をそのまま供試 5 調查地区に適応させらることの妥当 性を示すものともいえる。

つぎに 5 調查地区それぞれの雑草群落の平均反応数と 土壤酸度との関係を示せば第 1 図の通りである。
第 1 図によれば村松地区の原野区では，雑草群落の平 均反応数 $1.0 \sim 2.0$ が土壌 $\mathrm{pH}(\mathrm{KCl}) 4.00 \sim 4.38$ に, 未 熟畑区では $2.2 \sim 3.5$ が 4.60 4.88に，また熟畑区では $3.6 \sim 4.8$ が5. 20 5. 65 に分布している。他の 4 調査地 区では，原野区，末熟畑区ならびに熟畑区の順に，金井 地区では雑草群落の平均反応数 $1.0 \sim 1.8$ が土壤 $\mathrm{pH}$ (KCl) 3.75 4.05, 2.3 3.9 が 4. 50 5. 10 ならびに 3.5 5. 0 が5. 60 5. 95 に，妙高高原地区では 1.0 2.0 が 4.33〜4.72, 2.2 3.5が 4.95 5. 38 ならびに 3.5〜 4.8 が5.80 6.21に，また長嶺地区では $1.0 \sim 2.0$ が 4. 20 4. 48, 1.7 3. 5 が4.85 5. 25 ならびに 3.2 5. 0 が5.42 5.88に，さらに，十日町地区では $1.0 \sim 1.8$ が
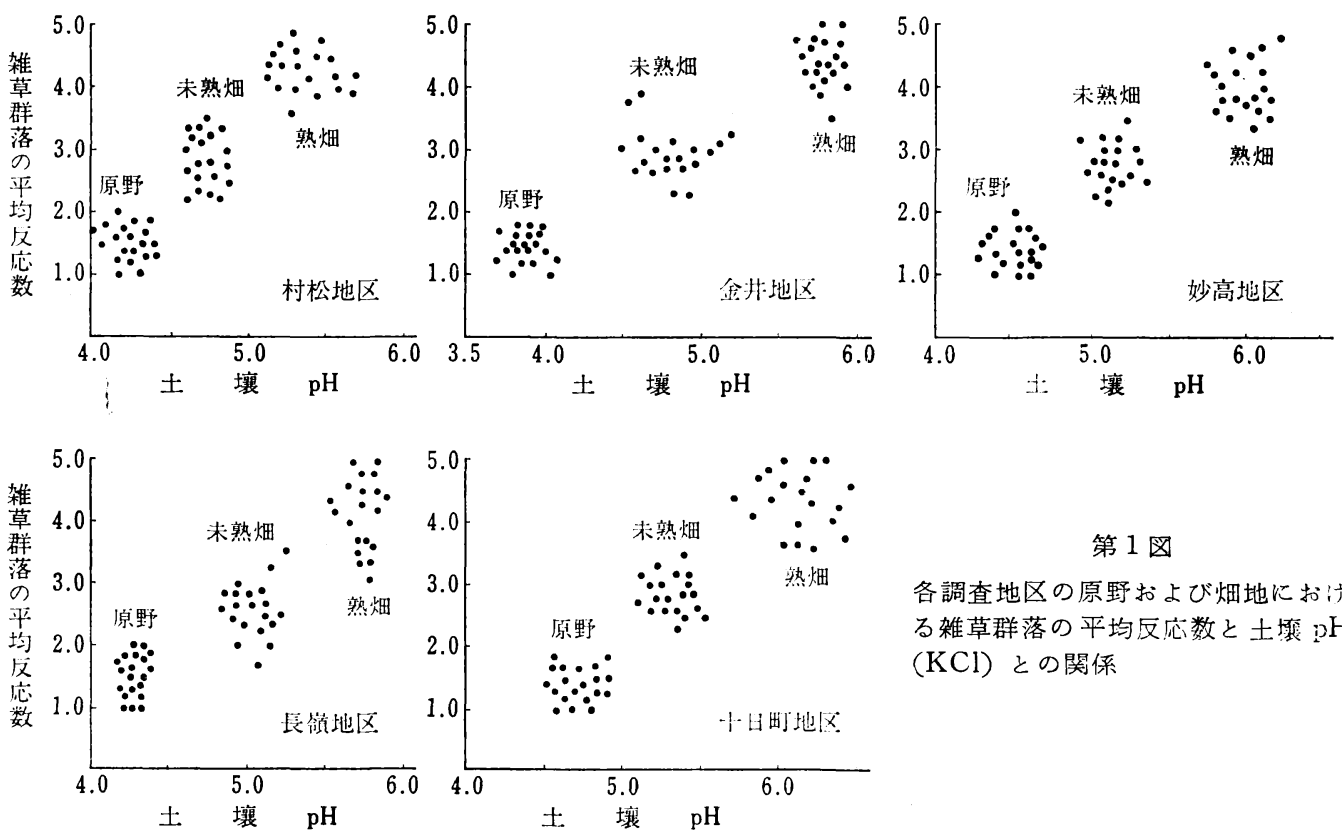

第 1 図

各調査地区の原野および畑地にお汸 る雑草群落の平均反応数と土壤 $\mathrm{pH}$ ( $\mathrm{KCl})$ との関倸
4. 50〜4.92，2.3〜3.5 が5. 11〜 5. 51 ならびに 3.7〜5.0 が5.72 6.58に分布している。

このように, いずれの調査地区においても, 原野区で は低い雑草群落の平均反応数を示すのに対し熟畑区では きわめて高い反応数を示し，未熟畑区は概ねその中間を 示す傾向が共通している。すなわち, 土壤酸度が強けれ ば雑草群落の平均反応数の数值が小さく, 逆に土壌酸度 が弱ければ反応数の数值が大になるといった傾向で，全 体を通じ村松地区では $r=0.7875^{* *}$, 金井地区では $r=$ $0.6976 * *$, 妙高高原地区が $r=0.8263 * *$, 長嶺地区が $r=0.7769 * *$ ならびに十日町地区が $r=0.7673 * *$ とき わめて高度の有意差を示している。しかしながら， 5 試 験地区を通じ，その中の原野区，未熟畑区ならびに熟畑 区のいずれか一つだけを抽出しても，そのいずれも有意
差を認めることができない。これらについては, 調査し たプロット数が 20 地点で少なすぎたことによるものか 否か不明ではあるが, 一方, 原野が開墾され, 土壃改良 が行なわれて化学的性質がある段階に達すると雑草植生 もそれに応じた形でかなり安定してくることを示してい るものとみられる。

著者はかつて村松地区において長年月を費し，土堙 $\mathrm{pH}(\mathrm{KCl}) 4.40$ 以下, 塩基置換酸度 $\left(\mathrm{y}_{1}\right) 10.0$ 以上, 石 灰飽和度 $20 \%$ 以下で原野状態の雑草植生, この段階を 越え $1 \sim 2$ 年の過渡期を経て未熟畑の植生に転換し, さ らに $\mathrm{pH}(\mathrm{KCl}) 5.00$ 以上, $\mathrm{y}_{1} 1.0$ 以下ならびに石灰飽 和度 $50 \%$ 以上で熟畑の植生に突入することを究明した が11), 本調査の 5 地区に拉いても, それぞれの段階の数 值が異なるにしても, 植生転換の化学的性質の段階が存 
在するもののようにみられる。また，5つの調査地区の 末熟畑区および熟畑区の土壤酸度は, 围場開設後これに 加えられた人為的諸操作によって異なるのがむしろ当然 であるが，原野区の酸度がかなり異なるのに同じような 植生である点が注目される。すなわち，同じ原野でも金 井地区では $\mathrm{pH}(\mathrm{KCl}) 3.75 \sim 4.05$ であるのに対し十日 町地区では 4.50 4.92 とかなり異なるのに, 雑草群落 の平均反応数は共に 1.0 2.0 程度の原野状態の 雑草植 生である。

このように，同じ火山灰黒ボク土壌からなる原野で著 しく酸度が異なるのは，土壤生成の新旧に起因するもの で，金井や村松地区など比較的古い火山灰土壌は長期間 風雨にさらされ含有塩類の溶脱が多いため強酸性を示す のに対し，十日町や妙高高原地区は比較的新しい火山灰 土壤からなり，土壤中に $\mathrm{Ca}, \mathrm{Na}, \mathrm{Mg}$ などの塩類を多 く含有するためと考えられる。しかして，上記金井と十 日町地区の原野の土壤酸度に著しい相異がみとめられた が，同じような雑草植生であったということは，共に耕 耘が行なわれず，それぞれ $\mathrm{y}_{1}$ が 17.52，14.31 ならびに 石灰飽和度が $4.05,8.05 \%$ 程度であった点からみて， 酸度の弱い十日町地区といえども未熟畑状態の植生に突 入できない段階であるとみられる。

いずれにしても 5 調査地区の対応する原野区，末熟畑 区ならびに熟烟区それぞれの土壤酸度がかなり異なるの に, 雑草の植生や雑草群落の平均反応数がさほど相異が みられなかったことは, 火山灰黒ボク土壤においては雑 草は酸度に対する強弱の性質は保有しているが, 必ずし も固定された $\mathrm{pH}$ の範囲や段階に限定されているもので はなく，個体の発生としては相当広範囲を示すもののよ らにみられる。例えば, 序数 1 のシバは金井地区の原野 区で $\mathrm{pH}(\mathrm{KCl}) 3.70 \sim 4.00$ に発生しているのに対し十 日町の原野区では 4.74 4.91 に, また, 未熟烟区で序数 3 のヒメスイバは村松地区で $\mathrm{pH}(\mathrm{KCl}) 4.65 \sim 4.83$ に 発生しているのに対し十日町地区では 5.82 5.95に, 熟烟区で序数 5 のエノキグサが金井地区で $\mathrm{pH}(\mathrm{KCl})$ $5.60 \sim 5.68$ に対し十日町地区では $6.28 \sim 6.50$ といった 状態である。

このように，地域の異なる火山灰黒ボク土壤に抢い て，序数を有する草種の $\mathrm{pH}$ 值の段階や範囲注かなり異 なるが, 全体的にみれば雑草群落の平均反応数の点で原 野区ならびに畑地区間に画然たる相異がみとめられる。 この事実は, 先に村松地区で求められた個々の草種の土 鏆酸度に対する強弱の傾向を整理した一覽表を尺度とし て，そのまま 5 調査地区に適応させうるとともに，それ らの各地区で求められた雑草群落の平均反忘数や土㵝酸
度などから熟畑化の程度を判定し，その指標たりらるこ とを実証するものであると思考される。

つぎに, 本調査地区の標高は村松地区が海抜 $24 \mathrm{~m}$ で 最低, 妙高高原地区が $672 \mathrm{~m}$ で最高を示し, また, 年平 均気温が, 村松地区が $13.1^{\circ} \mathrm{C}$, 金井地区が $13.8^{\circ} \mathrm{C}$, 妙 高高原地区が $12.0^{\circ} \mathrm{C}$, 長嶺地区が $13.0^{\circ} \mathrm{C}$ ならびに十日 町地区が $12.8^{\circ} \mathrm{C}$ で必ずしも一定していない。エレンベ ルグ2)によれば, 雑草群落の平均反応数を土䇎や気候の 指標として用いることができるとしているが，本実験の 限りでは, 限られたごく一部の地区の火山灰黒ボク土壤 においては熟畑化過程の指標として利用可能であるが, 標高や気候の指標として関係づけるまでには至っていな い。今後, さらに多数の草種の序数が判明し，それを用 いてわが国の多数の地域や異なる土壤についての実験が 行なわれ，その成果を総合すればその可能性も生じてこ よう。

つぎに，本実験の方法では，そのプロットに存在する 草種名とその序数さえ判明すれば, 至極簡単に雑草群落 の平均反応数を表示できるが, この場合, 序数を有しな い草種の取扱いや, 個々の草種の個体数, 草重, 被度な どについて顧虑すべきか否かの問題が残る。これらの点 については今後検討を加える必要がある。

本研究の結果から, 少なくとも供試した 5 調查地区の 畑地においては, 存在する雑草群落の平均反応数からあ る程度熟烟化の進捗状態を推定することができるととも に, 一方, 土壤の酸度が判明すれば, その位置に発生す る草種や群落の構成も概ね推定することが可能である。 例えば，村松地区のある地点で土㩙 $\mathrm{pH}(\mathrm{KCl})$ が 4.15 であったとすれば，そこに発生する雑草群落の平均反応 数は 1.5 程度で, 発生する草種としてはシバ, チガヤ, ススキ,イタドリ, カワラケツメイなどが主体をなし, 原野あるいはこれに準ずる新開墾畑の状態にある。ま た, 烟地で $\mathrm{pH}(\mathrm{KCl}) 4.75$ であったとすれば, 雑草群 落の平均反応数が 2.5 前後で, メヒシバ,エノコログ サ, アカザ, ヒメスイバ, サクラタデなどを主体とし， これにヨモギ, ギシギシ, オオマツョイグサなどが加入 するほか, ブタクサ, アレチノギク，チドメグサ，ミノ ボロスゲなど多数の特殊雑草が混生して未熟畑初期段階 の植生発現を推定できる。さらに, 土㙵 $\mathrm{pH}(\mathrm{KCl})$ が 5.60 であったとすれば, 雑草群落の平均反忘数が 4.0 前後で, メヒシバ, エノコログサ, コゴメカヤツリ, エ ノキグサ, スベリヒユ, ツユクサ, ザクロソウなどを主 とし，このほか多数の畑地雑草が混入してすでに完全な 熟畑段階の植生発現を推定できるなどである。

このように, 雑草群落の平均反応数によって熟怞化の 
程度を判定し，また，逆に土壌酸度によってあらかじめ 発現する雑草群落の形態を推定することが可能であると いうことは, 実際の雑草防除対策上きわめて有利な点が 多い。すなわち, 雑草の生態的防除を行ならため土壌酸 度矯正に要する石灰質資材の調達や投入量の決定, 化学 的防除を行なうための除草剤の選択や数量の決定, ある いは機械的防除法を行ならための除草作業機の選択や作 業体系の工夫などである。従来, 畑地における除草作業 は, 雑草発生の根源や植生転換の機棈を探究することな く, 単にあらゆる方法を講じて当面する雑草防除の方法 のみを追求してきたきらいなしとせず，また，土壤改良 の面においても, 土壤の理化学的性質改良にともなう作 物の生産性向上に力点をおくあまり, 雑草への対策が少 なかったようにみられる。実際, 開墾直後の畑地や大面 積対象の畑作経営では除草作業方法の適, 不適がそのま ま営農自体の成否を決定する場合が多く, 他方, 大量の 除草剤使用が人間をも含めた自然の生態采破壊の危惧を もたれている現在, 合理的な総合雑草防除体系確立の基 礎としても, 本研究でこころみられたような方向が重要 な意味をもつものと思考される。

\section{摘要}

1) 本研究は, 新潟県村松地区の火山灰黒ボク土壌地 帯で求められた雑草草種の土壌酸度に対する強弱の序数 を用いて, 地区の異なる県内 4 地区の同種の土㙥に適応 させうるか否かについて検討した。

2）新潟県の金井, 妙高高原, 長嶺, 十日町いずれの 地区でも原野, 未熟畑ならびに熟畑には序数を有する草 種が多く, 雑草群落の平均反応数間には高度の有意差が 認められた。したがって, 村松地区で得られた尺度を適 用する妥当性が究明された。

3）雑草群落の平均反応数を求める場合, 調査地点を 多くとれば, 序数を有しない草種や序数を有する草種の
個体数，草種などを考虑しなくともよいように考えられ る。

4) 今後, 多数の雑草の序数が決定され，また多数の 地域や異なる土壤地帯で, 雑草群落の平均反忘数と土壤 酸度との関係が究明されれば, それらの成果を総合編成 することにより，わが国いずれの地城でも適合できる土 壌や気候の指標を作成する可能性があるように考えられ る。

5）本研究を実施した火山灰黑ボク土䗙地帯の原野や 畑地では, 雑草群落の平均反応数がわかれば熟畑化の程 度を判定でき, 逆に土壌酸度がわかれば発生する雑草草 種や群落の様相をある程度予知することができ, 雑草防 除の対策上益する点がきわめて大である。

\section{引用文 献}

1) CARriex, H.: Lespedeza as a forage crop. Farmers Bulletin. pp. 1143 (1920).

2) Ellenbera, H.: Unkrautgemeinschaftin also zeiger für Klima und Boden. pp. 50 55 (1950).

3）笠原安夫：本邦雑草の種類及地理的分布の研究 第 3 報 木邦畑地 雑草の地理的分布と発生度. 農学研究 39, 91 106 (1951).

4）草下正雄・粶川卓郎：雑草に上る苗畑地力の判定. 日林誌 33,18 $\sim 21$ (1951).

5）沼田 真・大贺宣彦・大竹壮一・東百合子：雑草群落避移的意義飞 その指瀬的意義. 雑草研究第 4 回講演要旨. (1963).

6) 沼田 真 : 雑草群落の生態的研究. 雑草研究 1, 3 8 (1962).

7）清水正元：酸性土壤地带並に石灰岩土堙地带飞打ける雑草の群落生 態学的研觉 第 1 報. 日作紀 19,75 81 (1950).

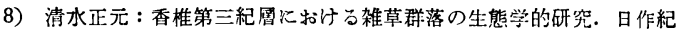
19, 275 279 (1951).

9）清水正元：酸性土境地带並汇石灰土㙲地带に扣ける雑草の群落生態 学的研究. 九大濃学芸誌 15, 25 33 (1955).

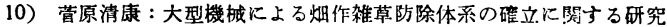

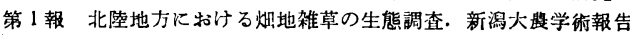
12, 57 77 (1960).

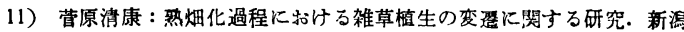
大農場報告 1，1２28（1971）。

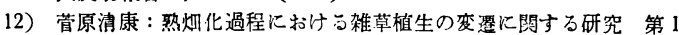
報 雑草草種の適応酸度について. 雑草研究 16, 53 57 (1973).

13）菅原清康：熟畑化過程飞おける雑草植生の变唫に閔与る研究 第 2 報 雑草群落表示の基楚としての土境酸度. 雑草研究 20 (1), 23 $\sim 29$ (1975)

(1975 年 7 月 2 日受付)

Studies on the Shifts in Weed Vegetation in the Maturation Process of Farms

3. A Correlation between an Average Responsiveness Index of Weed Populations and Soil Acidity in the Volcanic Ash-kuroboku Soil Zone

\section{Seikō SugAwara}

Muramatsu Farm, Faculty of Agriculture, Niigata University, Nügata

\section{Summary}

1. It was examined in the present study whether the ordinal number, an index of the responsi- 
veness of weed types to varying degrees of soil acidity, determined for weeds in the volcanic ashkuroboku soil zone in Muramatsu, Niigata Prefecture are applicable or not to weed types growing in soils of similar nature in other four localities in the same prefecture.

2. Data were collected from four districts such as Kanai, Myoko, Nagamine and Tokamachi. In all of these districts, many weeds sampled from uncultivated as well as immature and mature upland fields were found to be expressed by ordinal numbers. There was a highly significant difference among average responsiveness indice of different weed populations. These findings show that the classification system of weeds adopted in Muramatsu district can also be applicable to weeds in the other districts.

3. It appears that, if sampling points are large enough, an average responsiveness index can be obtained without referring to the individual number of weeds with or without an ordinal number and to the type of weeds.

4. Determination of ordinal numbers for may other weeds and the alucidation of a correlation between the average responsiveness index of weed populations and the soil acidity in many other districts of different soils might eventually enable to establish a standard index for soils or climate which would be applicable to every district of this country.

5. In uncultivated and cultivated upland fields in the volcanic ash-Kuroboku zone examined in this study, it was possible to know the maturity of a ffeld by knowing the average responsiveness index of weed population in the given field, and conversely it was possible to predict weed types or the structure of weed populations vegetating in a certain field by knowing its soil acidity. These features seem to be extremely advantageous for an effective operation of weeding.

\title{
ミズガャッリの開花と塊茎形成の光周反応
}

\author{
第2 報出穂反応 \\ 農業技術研究所 菅洋 \\ 農事試験場 草 雉 得一・服部金次郎
}

我代圈の上うに，南北に長く気候の多様な国土におい ては, 自生する雑草に種々の生態分化が形成されている ことは既に明らかにされている通りであるが，本邦雑草 におけるこの方面の知見は諸外国に比して著しくとぼし い。雑草のそのような生態分化を明らかにすることは, 防除技術の確立の上に重要な基礎的知見を提供するもの と思われる。本報告は, 本邦各地から採集したミズガヤ ツリの各系統について, 出穂の光周反応を調査したもの である。

\section{1. 実験材料と方法}

供試したミズガヤツリは 1968 年から 1970 年にわたっ て各地の県農試の好意で採集し, 埼玉県鴻巣市の農林省
農事試験場で保存中のものであるが，第 1 表に産地およ び区分を示した。各地で採取した材料の各々をここでは 系統として取り扱った。1973 年秋に固場より掘り取り, 湿潤低温 $5^{\circ} \mathrm{C}$ 下に保存しておいた塊茎を 1974 年 7 月 29 日にあらかじめ土壌をつめた $1 / 10,000$ a のプラスチッ クポットに, 1 ポットに 5 個の塊茎を植え付け, 以後常 に湛水状態で栽培した。肥料は元肥として, $\mathrm{N}: \mathrm{P}: \mathrm{K}$ $=13: 10: 12$ の粒状化成肥料を $2 \mathrm{~g}$ 宛施用した。植付け 後, 直ちに三つの日長条件, すなわち短日 (9 時間日 長), 自然日長, 長日 (20 時間日長) 下で生育させた。 日長処理の方法は第 1 報でのべた方法と同様である。

1 ポットに 5 個の塊茎を植え付けたが, 地下茎の繁殖 で個体の識別が困難であったため, 出穂日の決定には初 